OPEN ACCESS

Edited by:

Miquel A. Gonzalez-Meler, University of Illinois at Chicago, United States

Reviewed by:

Néstor Fernández Del-Saz, University of Concepcion, Chile Ambe Churchill,

University of Minnesota, United States

${ }^{*}$ Correspondence: Kevin L. Griffin

griff@ldeo.columbia.edu

Specialty section: This article was submitted to Plant Physiology,

a section of the journal Frontiers in Plant Science

Received: 23 July 2021 Accepted: 01 October 2021 Published: 01 November 2021

Citation: Griffin KL, Schmiege SC, Bruner SG, Boelman NT, Vierling LA and Eitel JUH (2021) High Leaf Respiration Rates May Limit the Success of White Spruce Saplings Growing in the Kampfzone at the Arctic Treeline.

Front. Plant Sci. 12:746464. doi: 10.3389/fpls.2021.746464

\section{High Leaf Respiration Rates May Limit the Success of White Spruce Saplings Growing in the Kampfzone at the Arctic Treeline}

\author{
Kevin L. Griffin ${ }^{1,2,3 *}$, Stephanie C. Schmiege ${ }^{2,4}$, Sarah G. Bruner ${ }^{2}$, Natalie T. Boelman ${ }^{3}$, \\ Lee A. Vierling ${ }^{5}$ and Jan U. H. Eitel ${ }^{5,6}$
}

'Department of Earth and Environmental Sciences, Columbia University, Palisades, NY, United States, ${ }^{2}$ Department of Ecology, Evolution and Environmental Biology, Columbia University, New York, NY, United States, ${ }^{3}$ Lamont-Doherty Earth Observatory, Columbia University, Palisades, NY, United States, ${ }^{4}$ New York Botanical Garden, Bronx, NY, United States, ${ }^{5}$ Department of Natural Resources and Society, College of Natural Resources, University of Idaho, Moscow, ID, United States, ${ }^{6}$ McCall Outdoor Science School, College of Natural Resources, University of Idaho, McCall, ID, United States

Arctic Treeline is the transition from the boreal forest to the treeless tundra and may be determined by growing season temperatures. The physiological mechanisms involved in determining the relationship between the physical and biological environment and the location of treeline are not fully understood. In Northern Alaska, we studied the relationship between temperature and leaf respiration in 36 white spruce (Picea glauca) trees, sampling both the upper and lower canopy, to test two research hypotheses. The first hypothesis is that upper canopy leaves, which are more directly coupled to the atmosphere, will experience more challenging environmental conditions and thus have higher respiration rates to facilitate metabolic function. The second hypothesis is that saplings [stems that are 5-10 cm DBH (diameter at breast height)] will have higher respiration rates than trees (stems $\geq 10 \mathrm{~cm} \mathrm{DBH}$ ) since saplings represent the transition from seedlings growing in the more favorable aerodynamic boundary layer, to trees which are fully coupled to the atmosphere but of sufficient size to persist. Respiration did not change with canopy position, however respiration at $25^{\circ} \mathrm{C}$ was $42 \%$ higher in saplings compared to trees $\left(3.43 \pm 0.19\right.$ vs. $\left.2.41 \pm 0.14 \mu \mathrm{mol} \mathrm{m}^{-2} \mathrm{~s}^{-1}\right)$. Furthermore, there were significant differences in the temperature response of respiration, and seedlings reached their maximum respiration rates at $59^{\circ} \mathrm{C}$, more than two degrees higher than trees. Our results demonstrate that the respiratory characteristics of white spruce saplings at treeline impose a significant carbon cost that may contribute to their lack of perseverance beyond treeline. In the absence of thermal acclimation, the rate of leaf respiration could increase by $57 \%$ by the end of the century, posing further challenges to the ecology of this massive ecotone.

Keywords: forest tundra ecotone, tree size, carbon balance, Picea glauca, high-resolution temperature response, dark respiration 


\section{INTRODUCTION}

At the global scale, plant respiration represents a massive flux of carbon from the biosphere to the atmosphere (Li et al., 2018) and thus plays a critical role in the global carbon cycle. Consequently, plant respiration needs to be well-described to predict rates of climate change (Atkin et al., 2015; Huntingford et al., 2017). While our understanding of biological and environmental controls of respiration rates remains incomplete, it is clear that temperature has a first order effect, setting up potential feedbacks between environmental change and respiratory $\mathrm{CO}_{2}$ release (O'Sullivan et al., 2013, 2017; Heskel et al., 2016). Understanding, quantifying, and predicting rates of respiration across scales of biological organization is an important challenge for science and thus humanity.

At the landscape scale, respiration represents a significant carbon loss and offsets photosynthetic carbon gain, which may have a controlling effect on ecosystem productivity. For example, eddy covariance studies across European forests identified respiratory processes as the controlling flux determining net ecosystem carbon exchange (NEE; Valentini et al., 2000). Furthermore, this work showed a clear latitudinal trend in NEE (increasing with decreasing latitude), despite a distinct lack of response in gross primary productivity, suggesting that respiratory fluxes have even stronger control on productivity in northern ecosystems. In addition, a synthesis of ecosystem model outputs from arctic and boreal ecosystems identifies both autotrophic and heterotrophic respiration as key "missing piece(s)" limiting modeling efforts in northern systems (Fisher et al., 2018). Uncertainty in autotrophic respiration alone can be as high as $25 \mathrm{~g} \mathrm{Cm}^{-2} \mathrm{month}^{-1}$, a flux, that is, in some boreal locations, five times the size of the uncertainty in NEE $\left(<5 \mathrm{~g} \mathrm{~m}^{-2} \mathrm{month}^{-1}\right.$, Fisher et al., 2018). The accelerated rate of warming near the poles (Cohen et al., 2014), the massive carbon stores across northern biomes (Fisher et al., 2014), and the uncertainty in the future strength of northern latitudes as a strong carbon sink (Schuur et al., 2015) all point to an acute need for understanding the response of respiration to temperature in these systems.

Respiratory control of ecosystem form and function may be particularly acute at the forest tundra ecotone (FTE). The FTE represents the transition from the boreal biome to the treeless tundra at higher latitudes. This vast transition zone is circumpolar and thus represents the largest terrestrial ecological transition zone found on the planet (Callaghan et al., 2002a,b). The distinct ecology of the FTE is of intense interest as climate envelope models predict that northern treeline could move rapidly towards the arctic ocean (ACIA, 2005; Pearson et al., 2013; Zhang et al., 2013), completely displacing the tundra in some North American locations and significantly altering the ecology (and carbon balance) of massive areas. While our understanding of the precise control of the location of the FTE is incomplete, ample evidence points to temperature as the primary driver (Callaghan et al., 2002a,b; Sveinbjornsson et al., 2002; Körner, 2012b and references therein). Clearly other environmental and biological factors can contribute to the maintenance of the northern treeline in specific locations and these include: soils, nutrition, drought, tree demography, herbivory, abrasion and exposure, and microtopography (Körner, 2012b and references therein; Maguire et al., 2019).

However, temperature is of particular interest since it is increasing rapidly in northern ecosystems (Cohen et al., 2014) where it can have a large effect on the rate of autotrophic respiration (Heskel et al., 2016) and is the critical driver of respiration in ecosystem models which contain large uncertainty in the carbon balance of northern ecosystems (Fisher et al., 2018).

This suggests a clear need for additional information regarding the temperature dependence of the physiological processes controlling northern ecosystem carbon balance including photosynthesis and respiration.

White spruce [Picea glauca (Monench) Voss] has a transcontinental range and is one of the most common tree species defining the FTE in North America (Sutton, 1969). Considered to be one of the hardiest coniferous species, white spruce has a suite of structural and functional traits that may help explain its persistence in the harsh FTE environment where tree growth can be limited by low winter temperatures, short growing seasons, extreme light environments, and often limiting rooting volumes due to the occurrence of permafrost. These potentially adaptive traits include strong apical dominance (Nienstaedt and Zasada, 1990), prolific seed production beginning at an early age (Sutton, 1969), xylem morphology capable of desiccation tolerance (Pampuch et al., 2020), strong photoperiodicity of growth (Eitel et al., 2019), early rehydration and initiation of growth despite experiencing extremely cold winters (Eitel et al., 2020), and rapid photoprotection mechanisms (Maguire et al., 2020), among many others. The physiology of white spruce is less well-characterized, but studies of both photosynthesis and respiration (e.g., Weger and Guy, 1991; Man and Lieffers, 1997; McNown and Sullivan, 2013; Stinziano and Way, 2017; Benomar et al., 2018; Prud'Homme et al., 2018) indicate the physiology of leaf carbon balance in white spruce is under strong environmental control that could contribute to the establishment and persistence of the FTE. Nevertheless, the response of respiration to temperature remains largely an enigma. A fuller understanding of autotrophic respiration, and its response to temperature in this important northern treeline species would provide mechanistic information, that is, critically needed to assess the rapidly changing ecology of northern forests, boreal forest carbon storage, and ultimately the location of the circumpolar FTE.

A robust quantification of average respiration rates at a common temperature alone is unlikely to provide sufficient understanding of the contribution of respiration to the structure and function of the FTE. Clearly, the temperature response must be described and typically the knowledge of thermal acclimation would also be required (Huntingford et al., 2017). However, previous work on this species suggests that thermal acclimation of leaf physiology is limited (Stinziano and Way, 2017; Benomar et al., 2018). Additional considerations include canopy position, as light acclimation has been shown to dramatically affect respiration rates in white spruce (Awada and Redmann, 2000), and intra-canopy gradients in light absorption may exist. Furthermore, the top of the canopy is 
often the most physiologically active portion of the crown and has been shown to affect both average respiration rates and the response of respiration to temperature (Griffin et al., 2001, 2002; Whitehead et al., 2004). An additional concern is the potential effect of size. Young saplings can be faster growing (Brienen et al., 2020) and thus may require higher rates of respiration to support the metabolic costs of growth (Reich et al., 2014; Colesie et al., 2020). Furthermore, it has been suggested (Körner, 2012a,b) that saplings [defined as being less than $10 \mathrm{~cm}$ diameter at breast height $(\mathrm{DBH})]$ are significantly more susceptible to the harsh climatic conditions existing at treeline, resulting in a high rate of mortality, that is speculated to contribute to the geographic location of the FTE. Recognized as the "kampfzone" in the literature (Körner, 2012b), this transitional area is characterized by an abundance of seedlings and shrub-like "krummholz" but a low number of saplings, that is, thought to be the result of an aerodynamic boundary layer. Within this warm, still boundary layer conditions are conducive to growth, permitting seedling regeneration, and krummholz survival (Körner, 2012b). However, beyond the boundary layer, saplings must survive the more variable and extreme environmental conditions which arise as their increased size couples them to the atmosphere. To our knowledge, the relationships between tree size (and thus strength of the coupling to the atmosphere) and physiological function have not been studied at the FTE. Finally identifying potential proxies for respiratory function such as leaf nitrogen concentration (e.g., Griffin et al., 2001) could substantially simplify ongoing efforts to model and track the ecology and location of the FTE.

Working at an established FTE experimental site in northern Alaska (Eitel et al., 2019), we test two research hypotheses. The first hypothesis, that the leaves at the top of the canopy (within $1 \mathrm{~m}$ of the apical meristem) will have higher respiration rates but a more muted response to temperature than leaves at the bottom of the canopy ( $1.37 \mathrm{~m}$ from the ground). The logic for the first prediction stems from the discussion above and the concept of the "kampfzone," since the top of a tree tends to be more metabolically active, and the top of the canopy is more strongly coupled to the atmosphere than the bottom of the canopy. Strong atmospheric coupling would suggest that leaves at the canopy top experience a greater range of leaf temperatures which would result in a reduced respiratory response over a similar range of temperatures (Atkin and Tjoelker, 2003). The second hypothesis tested is that saplings $(<10 \mathrm{~cm} \mathrm{DBH})$ will have higher respiration rates but a more muted response to temperature than trees $(>10 \mathrm{~cm} \mathrm{DBH})$. The logic for the second prediction again comes from the concept of the kampfzone, suggesting that saplings are more susceptible to the harsh climatic conditions existing at treeline, which we predict would result in higher metabolic costs and result in higher average respiration rates but a more muted response to temperature. In addition to testing these two research hypotheses, we explore differences in $T_{\max }$ (the maximum temperature at which respiration continues to increase, signifying leaf death and therefore maximum temperature tolerance) and the relationships between respiration and leaf nitrogen, since leaf nitrogen is often used to predict rates of respiration (e.g.,
Atkin et al., 2015). We stress that rapid Arctic warming is likely to result in a significantly greater respiratory loss of carbon in trees and ultimately this puts the future of the arctic and boreal carbon sink in question. By quantifying thermally induced changes in respiratory carbon fluxes, we add critically needed mechanistic information and extend our understanding of ecosystem form and function at the FTE.

\section{MATERIALS AND METHODS}

\section{Site Description and Leaf Material}

Our experimental sites are located in northern Alaska, on the southern side of the Brooks Range along a $5.5 \mathrm{~km}$ long stretch of the Dalton Highway $\left(67^{\circ} 59^{\prime} 40.92^{\prime \prime N}\right.$ latitude, $149^{\circ} 45^{\prime} 15.84^{\prime \prime} \mathrm{W}$ longitude) and are described more fully in Eitel et al. (2019). Picea glauca (white spruce) is the only tree species at these sites, with the only exceptions being the rare black spruce tree [P. mariana (Mill.) Britton, Sterns and Poggenb.], or the more common smaller multi-stemmed red alder (Alnus rubra Bong.). The understory contains deciduous shrubs, sedges, forbs, and mosses, which are also common in the treeless tundra just beyond the sites (to the north or higher in elevation). The sites are underlain by continuous permafrost and tend to be quite wet. The location is characterized by cold temperatures (annual average $=-8.1^{\circ} \mathrm{C}$ ) and modest precipitation $\left(485.4 \mathrm{~mm} \mathrm{yar}^{-1}\right)$, as measured from a nearby Snow Telemetry (SNOTEL) site. ${ }^{1}$

The six sites were established along the Dietrich River flood plain in 2016 (Eitel et al., 2019). At each site, a circular plot with $10 \mathrm{~m}$ radius $\left(314 \mathrm{~m}^{2}\right.$ area) was established, and six white spruce trees from two different size classes were tagged. The size classes were chosen according to Körner (2012b) to differentiate "trees" ( $\geq 10 \mathrm{~cm} \mathrm{DBH})$ from "saplings" ( $<10 \mathrm{~cm} \mathrm{DBH})$.

In June 2018, leaves were sampled from two locations for each of the 36 target trees, made up of 18 saplings and 18 trees, for gas exchange analysis. The terminal portions of several branches were cut with sharp pruners (bottom of the canopy) or a pole clipper (top of the canopy), and the removed portion of the stem was immediately wrapped with wet paper towels, sealed in a plastic bag with ample air and placed in a cooler where they were kept in the dark until arriving in the lab. The location of the lower samples was approximately $1.37 \mathrm{~m}$ above the ground, and were collected from the south side of the canopy. The location of upper samples was approximately $1 \mathrm{~m}$ from the terminal apex of each tree, and were collected from the south side of the canopy. Once returned to the lab, the stems were recut underwater and placed in a beaker containing enough water to keep the cut end submerged until analyzed, typically within 8 , but no more than $24 \mathrm{~h}$.

\section{Respiration Temperature Response Curves}

To assess average respiration rates at a common temperature $\left(25^{\circ} \mathrm{C}, R_{25}\right)$ and to quantify the response of respiration to

${ }^{1}$ https://wcc.sc.egov.usda.gov/nwcc/site?sitenum $=957$ 
temperature, $\mathrm{CO}_{2}$ exchange rates were measured. The individual leaves (needles) were carefully removed from the stems to avoid the large contribution the stem would otherwise have made to the $\mathrm{CO}_{2}$ flux thereby confounding the results (e.g., Heskel et al., 2014). These needles were weighed to determine the initial fresh mass ( $g$ ) and then placed in a fine nylon mesh bag, allowing for easy air flow through the bag while keeping the leaves from entering the optical bench of the infrared gas analyzer or becoming lost in the leaf cuvette. The mesh bag containing the leaves was placed inside a custom-made cuvette milled from a solid block of aluminum with a plexiglass lid sealed with a Viton gasket (Patterson et al., 2018; Li et al., 2019; Schmiege et al., 2021). The cuvette contained a mixing fan and two fine wire thermocouples to measure leaf and air temperatures. Temperature was thermoelectrically controlled from a laptop computer (using a CP-121 Thermoelectric Peltier Cooling Unit, TE Technology, Traverse City, MI, United States). The custom cuvette was interfaced with a portable photosynthesis system (Li-6800XT; LiCor Lincoln, Nebraska, United States).

Before each measurement, the system was both equilibrated to $5^{\circ} \mathrm{C}$ and zeroed. The mesh bag holding the leaves was then sealed inside the cuvette and the system was again equilibrated to $5^{\circ} \mathrm{C}$. Once stability was reached, the temperature response curve was measured as described in previous studies ( $\mathrm{O}^{\prime}$ Sullivan et al., 2013; Heskel et al., 2016; Schmiege et al., 2021). Conditions during the measurements included a flow rate of $500 \mathrm{ml} \mathrm{min}^{-1}$ through the cuvette, and a reference $\mathrm{CO}_{2}$ concentration of $400 \mathrm{ppm}$. The incoming air was dried using the Li-6400XT desiccant column and transpiration was allowed to humidify the air as done previously (see references above). During the measurement, the cuvette temperature was ramped continuously from 5 to $65^{\circ} \mathrm{C}$ at a constant rate of $1^{\circ} \mathrm{C} \mathrm{min}^{-1}$. All gas exchange variables and calculated rates were recorded every $20 \mathrm{~s}$ by the Li-6400XT.

\section{Leaf Traits}

Upon the completion of the temperature response curve, the leaves were removed from the cuvette and photographed with a known scale. ImageJ software (Schneider et al., 2012) was used to determine the projected area of these needles. The leaves were transferred to coin envelopes and dried at $65^{\circ} \mathrm{C}$ for a minimum of $48 \mathrm{~h}$. Dried leaves were again weighed to determine leaf dry mass $(\mathrm{g})$. Specific leaf area (SLA $\mathrm{cm}^{2} \mathrm{~g}^{-1}$ ) was calculated and used to interconvert between area- and mass-based respiratory fluxes. Leaf water content (\%) and leaf dry matter content (LDMC) were calculated from the fresh and dry masses. Leaf nitrogen was estimated using the $\% \mathrm{~N}$ measured from these same trees, sampled at the same canopy locations in 2017 (Schmiege et al., unpublished).

\section{Data Analyses}

The respiration temperature response curves were analyzed as in Heskel et al. (2016) by fitting a second-order polynomial model to the $\log$ transformed respiration rates between 10 and $45^{\circ} \mathrm{C}$ :

$$
L n R=a+b T+c T^{2}
$$

where $a$ represents the basal respiration rate $(y$-intercept), and $b$ and $c$ describe the slope and curvature of the response (Heskel et al., 2016). From these modeled curves, we also derived the respiration rate at a common temperature of $25^{\circ} \mathrm{C}$ $\left(R_{25}\right)$. Using the entire data set between 5 and $65^{\circ} \mathrm{C}$, the temperature of the maximum respiration rate was extracted $\left(T_{\max }\right)$.

Before statistical analysis, all traits were transformed as necessary to fulfill statistical assumptions of normality. Statistical differences in $P$. glauca traits between large trees and small saplings including DBH and tree height were assessed using an independent sample $t$-test.

To test our hypothesis regarding the main effects of canopy position or tree size on all respiratory parameters (including the polynomial model parameters $a, b$, and $c$, area- and mass-based $R_{25}$, and $T_{\max }$ ) and leaf traits (including SLA, LDMC, and $\% \mathrm{~N}$ ), we used a linear mixed effects model allowing us to incorporate each unique tree as a random effect, since both canopy positions were used for these analyses (using the lme4 and the lmerTest packages; Bates et al., 2015; Kuznetsova et al., 2017, respectively). Finally, model coefficients from our study were compared to those from Heskel et al. (2016) for the Tundra and Boreal biomes, as well as the needle-leaved evergreen (NLEv) plant functional type using the information contained within their Table 1, with an independent sample $t$-test. For all analyses, statistical significance was assessed using a value of $p$ of 0.05 . Data analysis was done in either R version 3.6.3 (R Core Team, 2020) or Microsoft Excel $^{\circledR}$.

\section{RESULTS}

\section{Tree and Leaf Traits}

The average tree in this study was $11.52 \pm 6.73 \mathrm{~cm}$ in DBH $(1.37 \mathrm{~m}$ from the ground, Table 1). When divided into two size classes, the saplings $(5-10 \mathrm{~cm} \mathrm{DBH})$ were on average $60 \%(\sim 10 \mathrm{~cm})$ smaller than the trees $(\geq 10 \mathrm{~cm} \mathrm{DBH}$; Table 1). In addition, trees were $55 \%$ taller than the sapling class. None of the measured leaf traits differed by size class (trees vs. saplings, Table 1).

\section{Respiration Temperature Response Curves}

All leaves showed a similar response to temperature during the high-resolution measurements, increasing exponentially between approximately 5 and $45^{\circ} \mathrm{C}$, then slowing briefly before increasing with rising leaf temperatures to a maximum rate of respiration at $T_{\max }$ (Figure 1A). To model the ecologically relevant response, the data were limited to between 10 and $45^{\circ} \mathrm{C}$ and the $\log$ normal response was fit with the global polynomial model of Heskel et al. (2016; Figure 1B, equation 1 above). This model fit all curves remarkably well with $r^{2} \geq 0.99$ in all cases. Overall, the three model [see Eq. (1)] coefficients averaged $-0.931 \pm 0.069, \quad 0.083 \pm 0.002$, and $-0.00023 \pm 5.5 \times 10^{-5}(a, b$, and $c$ respectively, mean \pm SEM $)$. There was no statistically significant effect of canopy position on any of the model fits, model coefficients or derived variables (data not shown). However, saplings did differ significantly 
TABLE 1 | Tree and leaf characteristics of Picea glauca trees $(\geq 10 \mathrm{~cm} \mathrm{DBH})$ and saplings $(5-10 \mathrm{~cm} \mathrm{DBH})$ growing in the FTE in Alaska.

\begin{tabular}{|c|c|c|c|c|c|}
\hline & DBH cm & Height m & SLA $\mathrm{cm}^{2} \mathbf{g}^{-1}$ & LDMC & $\mathbf{N}^{*} \%$ \\
\hline Saplings & $6.58 \pm 0.25^{\mathrm{a}}$ & $4.18 \pm 0.18^{a}$ & $21.99 \pm 0.35^{a}$ & $0.54 \pm 0.004^{a}$ & $0.93 \pm 0.02^{\mathrm{a}}$ \\
\hline Trees & $16.60 \pm 0.68^{b}$ & $9.36 \pm 0.41^{b}$ & $21.84 \pm 0.35^{\mathrm{a}}$ & $0.54 \pm 0.004^{a}$ & $0.99 \pm 0.02^{a}$ \\
\hline
\end{tabular}

$D B H$, diameter at breast height (1.37 m); SLA, specific leaf area; LDMC, leaf dry matter content (g dry mass $\mathrm{g}^{-1}$ fresh mash); and $\mathrm{N}$, leaf nitrogen \%. "Leaf nitrogen data collected from the same trees in 2017, by Schmiege. $n=36$ for both trees and saplings, 72 for all trees. Different letters following the means denote statistically significant differences.

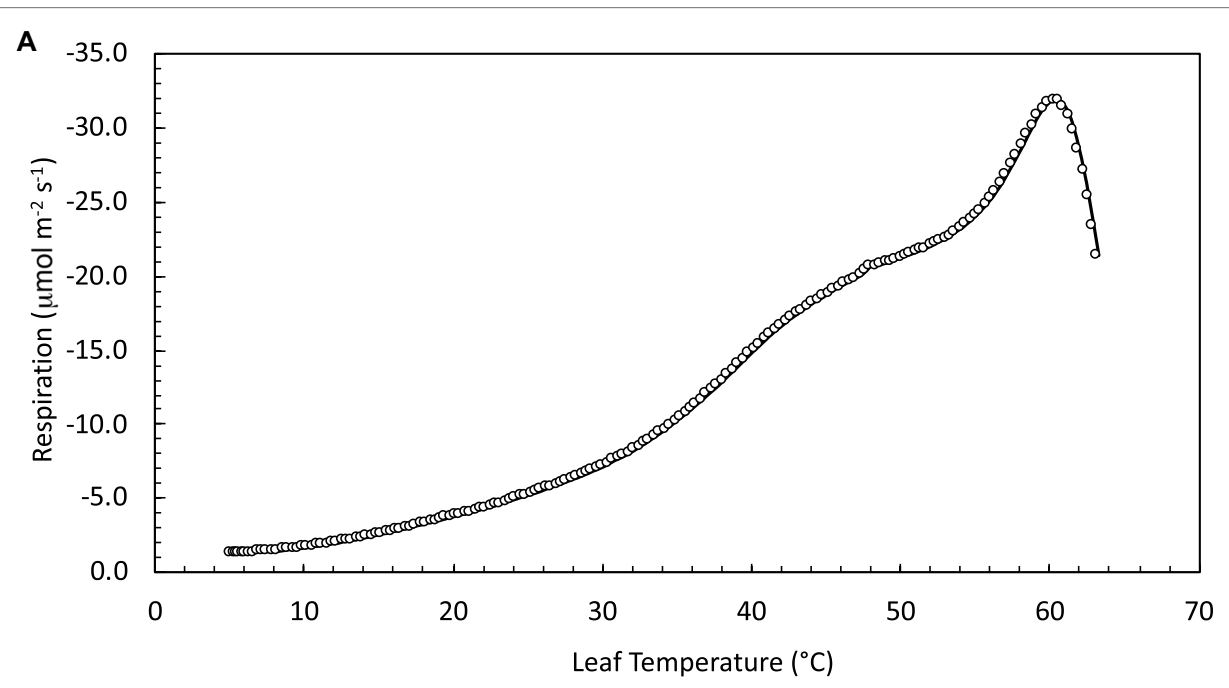

B

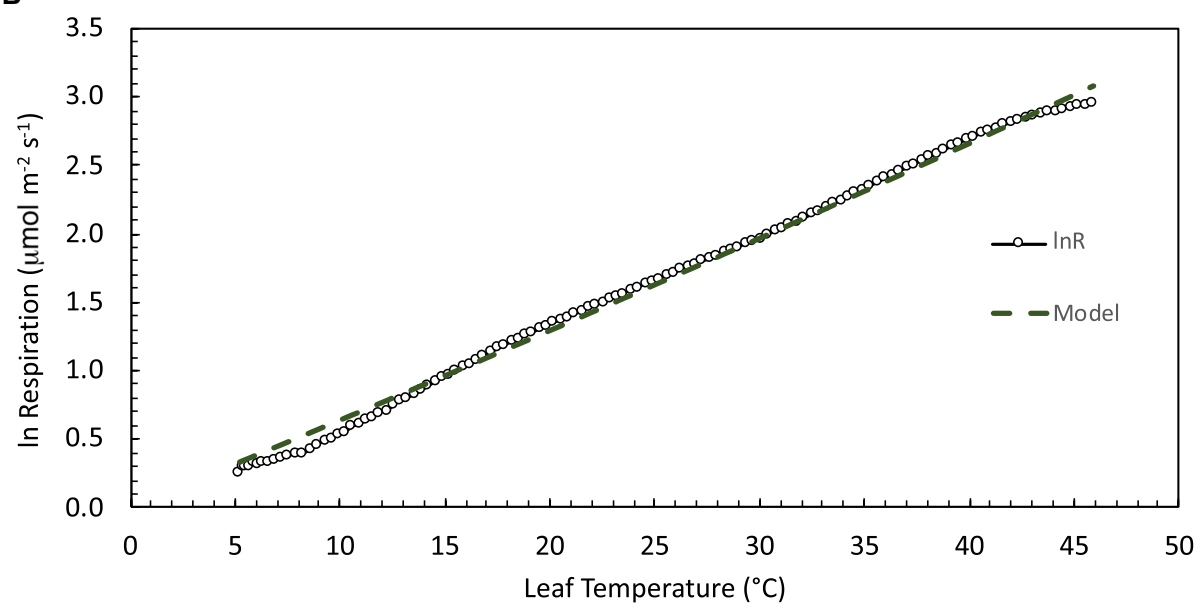

FIGURE 1 | Leaf respiration as a function of temperature in Picea glauca measured at the forest tundra ecotone (FTE) in Alaska. (A) An example of the highresolution temperature response curves measured from 5 to $65^{\circ} \mathrm{C}$. Air temperature was heated at a rate of $1^{\circ} \mathrm{Cmin}^{-1}$ while the rate of $\mathrm{CO}_{2}$ release and other gasexchange parameters were recorded every $20 \mathrm{~s}$. (B) The log of measured respiration rate and model fit $\left(n R=a+b T+c T^{2}-\right.$ see text for full description) between 10 and $45^{\circ} \mathrm{C}$ (the ecologically relevant temperature range) for the same sample.

from trees (Table 2; Figure 2). The intercept (coefficient a) of the $\operatorname{lnR} / \mathrm{T}$ response of saplings was $38 \%$ lower than basal respiration for the trees. Neither the slope nor the curvature (coefficients $b$ and $c$ ) of the $\ln \mathrm{R} / \mathrm{T}$ relationships differed between trees and saplings (Table 2; Figure 2). The response of white spruce respiration to varying temperature differs from the average response for species in the NLEv plant functional type and both the Tundra and Boreal biomes in the global compilation of Heskel et al. (2016; Figure 3). In all cases the a coefficient of both our trees and saplings differed significantly from the a coefficient of the Tundra or Boreal Biomes, and the NLEv PFT of Heskel et al. $(2016 ; p<0.5)$. While the slope and curvature ( $b$ and $c$ coefficients) were statistically similar for the comparisons of either the FTE trees or saplings with the Boreal Biome, both FTE groups differed from the Tundra biome and NLEv PFT. 


\section{Respiration at a Common Temperature and $T_{\max }$}

Across all samples, the average rate of respiration at a common temperature of $25^{\circ} \mathrm{C}$ was $2.92 \pm 0.135 \mu \mathrm{molCO}_{2} \mathrm{~m}^{-2}$ leaf area $\mathrm{s}^{-1}$. This rate did not differ by canopy position but did vary between saplings and trees. Saplings had a significantly higher area-based $R_{25}$ than larger trees $\left(3.43 \pm 0.19 \mu \mathrm{molm}^{-2} \mathrm{~s}^{-1}\right.$ vs. $2.41 \pm 0.14 \mu \mathrm{mol} \mathrm{m}^{-2} \mathrm{~s}^{-1}, p<0.5$; Figure 4A). The $43 \%$ lower area-based rate observed in the tree $R_{25}$ was similar when converted to a mass basis $\left(0.00738 \pm 0.00036 \mu \mathrm{molg}^{-1} \mathrm{~s}^{-1}\right.$ vs. $0.00525 \pm 0.00032 \mu \mathrm{molg}^{-1} \mathrm{~s}^{-1}$ in saplings vs. trees respectively; Figure 4B). Saplings respire at leaf temperatures that were nearly $2^{\circ} \mathrm{C}$ higher than the $T_{\max }$ for large trees $\left(57.6^{\circ} \mathrm{C}\right.$; Figure 5). None of the respiratory parameters $\left(R_{25}, a\right.$ or $\left.T_{\max }\right)$ were significantly related to leaf $\mathrm{N}\left(\mathrm{mg} \mathrm{N} \mathrm{m}^{-2} ; F\right.$ significance $=0.13$, 0.18 , and 0.72 respectively, data not shown).

\section{DISCUSSION}

We show that saplings have significantly higher rates of leaf respiration than trees. This result supports our first hypothesis and is highly important as it ultimately may help explain the mechanistic underpinnings of the structure and function of

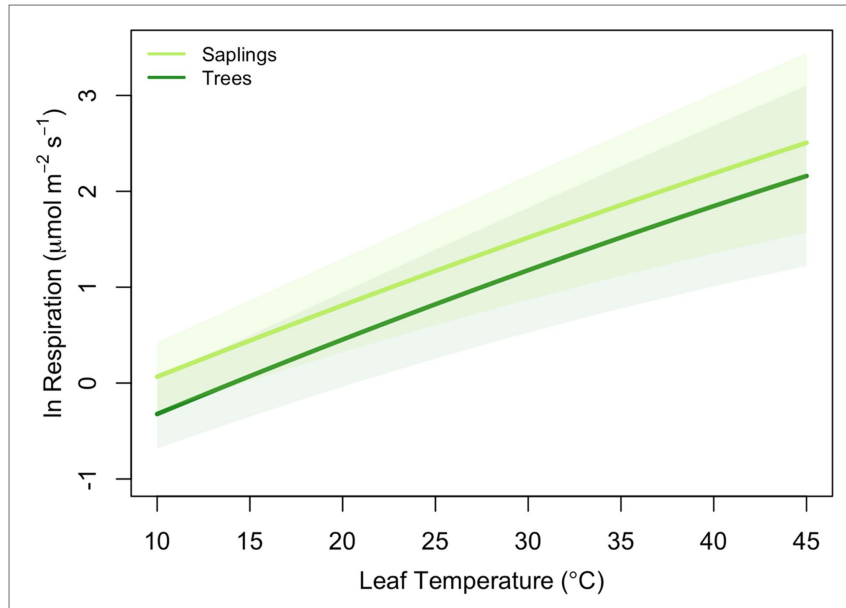

FIGURE 2 | Average model results (log of leaf respiration) for trees $[\geq 10 \mathrm{~cm}$ diameter at breast height (DBH) - dark green] and saplings $(5-10 \mathrm{~cm} \mathrm{DBH}-$ light green) of Picea glauca growing in the FTE in Alaska. Line presents the mean response $(n=36)$ and shaded area $=95 \%$ confidence interval for size class. Model parameters are presented in Table 2. the FTE. Any discussion of the FTE, the role of climate in determining its location, or the effect of climate change on its rate of migration, must begin with a definition of "tree." Here we adopt the terminology of Körner (2012a,b), who presents the following life stages: Germlings, in the year of germination; Seedlings, commonly $<15 \mathrm{~cm}$ tall; Saplings, with stem of less than $10 \mathrm{~cm} \mathrm{DBH}$, and finally; Trees, with $\mathrm{DBH}$ greater than $10 \mathrm{~cm}$. Since treeline, and hence the FTE, is defined by the lack of trees, the implication is that germlings, seedlings, and saplings growing at this transitional boundary between tundra and forest (the kampfzone), do not represent the permanent establishment of the boreal forest biome, as they are unlikely to survive. The question pondered by tens, perhaps hundreds of scientists, is - why are they unlikely to survive? Are there environmental and/or biological conditions that limit the transition to the tree lifeform? While dozens of possible explanations have been studied, and many variables deemed to contribute (locally), cold temperatures have always been the most likely constraint on the position of global treeline (both alpine and northern; Körner, 1998, 2012b; Körner and Paulsen, 2004). Our data provide mechanistic, physiological evidence that saplings incur higher respiratory costs without displaying thermal acclimation (compared to trees). These higher costs may result in carbon balance limitations that ultimately limit sapling survival.

White spruce is known as an extremely hardy and robust species that can persist for hundreds of years while growing very slowly (Sutton, 1969; Nienstaedt and Zasada, 1990). Slow growth can be part of a relatively common life history strategy that includes low photosynthetic rates and large investments in long lived leaves, and thus results in long returns on carbon investments (Poorter and Pothmann, 1992; Poorter et al., 2014; Reich et al., 2014). Adding high basal metabolic costs (high respiration rates) to this strategy could help explain the difficulty FTE saplings have in surviving the harsh conditions and short growing season. Previous work on white spruce (Man and Lieffers, 1997; McNown and Sullivan, 2013; Stinziano and Way, 2017; Benomar et al., 2018; Prud'Homme et al., 2018) demonstrate that it has, at best, modest maximum photosynthetic rates (typically less than $10 \mu \mathrm{molm}^{-2} \mathrm{~s}^{-1}$ ) and that these rates may be realized only rarely when the ambient environmental conditions are most favorable. Furthermore, McNown and Sullivan (2013) also present data from treeline in Northern Alaska, demonstrating that the net photosynthesis of white spruce can average less than $4 \mu \mathrm{mol} \mathrm{m}^{-2} \mathrm{~s}^{-1}$ while leaf respiration can exceed $2.5 \mu \mathrm{molm}^{-2} \mathrm{~s}^{-1}$. This leaves an exceptionally thin

TABLE 2 | Model parameters fit to the measured high-resolution leaf respiration temperature response curves collected from Picea glauca measured at the FTE in Alaska.

\begin{tabular}{|c|c|c|c|c|c|c|}
\hline & $a$ & $95 \% \mathrm{Cl}$ & $\boldsymbol{b}$ & $95 \% \mathrm{Cl}$ & $c$ & $95 \% \mathrm{CI}$ \\
\hline Saplings & $-0.7173^{a}$ & {$[-0.9728,-0.4618]$} & $0.0802^{a}$ & {$[0.0713,0.089]$} & $-0.00019^{a}$ & {$[-0.00033,-0.00005]$} \\
\hline$e^{x}$ & $0.56 \pm 0.04$ & & $1.08 \pm 0.0$ & & $1.00 \pm 0.0$ & \\
\hline Trees & $-1.154^{b}$ & {$[-1.4113,-0.8967]$} & $0.0858^{a}$ & {$[0.0769,0.0947]$} & $-0.00027^{a}$ & {$[-0.00041,-0.00013]$} \\
\hline$e^{x}$ & $0.37 \pm 0.04$ & & $1.09 \pm 0.0$ & & $1.00 \pm 0.0$ & \\
\hline
\end{tabular}

Results are separated by trees $(\geq 10 \mathrm{~cm} D B H)$ and saplings $(5-10 \mathrm{~cm} \mathrm{DBH})$. Mean response $(n=36)$ and $95 \%$ confidence interval for each size class. Differing letters following the means denote statistically significant differences. Back transformed means and standard errors are also presented below each model parameter. 
carbon margin to support growth and metabolic function (McNown and Sullivan, 2013; Figure 3). Unpublished data from our site (Schmiege et al.) find higher rates of net photosynthesis (collected in 2017, the year before the current respiration measurements) than those of McNown and Sullivan (2013), yet do not preclude the limiting carbon balance mechanism. In fact, the $R_{25}$ rates for saplings presented here average $3.4 \mu \mathrm{molm}^{-2} \mathrm{~s}^{-1}$, which are significantly higher than both those reported by McNown and Sullivan (2013), and the global average for needle-leaved trees $\left(\sim 1.25 \mu \mathrm{mol} \mathrm{m}^{-2} \mathrm{~s}^{-1}\right.$, GlobResp database, Atkin et al., 2015) demonstrating the potential for exceptionally high respiratory costs for saplings growing and attempting to establish themselves as trees in the

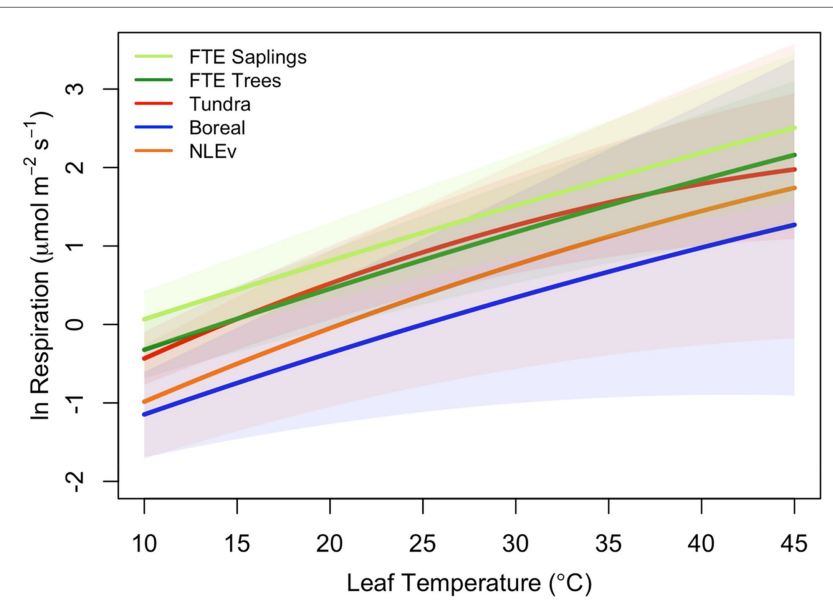

FIGURE 3 | Comparison of polynomial models fits from Heskel et al. (2016) with the average fits measured on two size classes of Picea glauca at the FTE in Northern Alaska. Response plotted are for the tundra biome (red line), boreal biome (blue line), needle-leaved evergreen plant functional type (orange line), FTE trees (>10 cm; dark green line), and FTE saplings $(5-10 \mathrm{~cm} \mathrm{DBH}$; light green line).
FTE. Interestingly, individual plants with $\mathrm{DBH}<10 \mathrm{~cm}$ (conventionally called "saplings") are routinely $>100$ years old at the FTE, further complicating assumptions about tree demography and implications of relatively rapid warming-induced respiratory losses for this critical size class.

Respiration at a common temperature $\left(R_{25}\right)$ is a useful tool for comparing across studies, across ecological settings, and across biomes (e.g., Atkin et al., 2015), but alone, is not a sufficient indicator of in situ respiratory activity. High-precision temperature response curves, like those presented here, can provide significantly more information and insight into how trees respond to changing local environmental conditions (O'Sullivan et al., 2013). Furthermore, coupling these measurements to models, such as the global polynomial model of Heskel et al. (2016) provides the tools for analyzing, comparing, and scaling the results (Huntingford et al., 2017). We find the intercept of the relationship between leaf temperature and the $\log$ of respiration (coefficient $a$ ), differs significantly between trees and saplings. This finding extends the $R_{25}$ result and again suggests a higher respiratory cost for saplings, even at cool $\left(<10^{\circ} \mathrm{C}\right)$ temperatures. Not only is the cost higher for FTE saplings, but overall, the costs are high compared to other NLEv, boreal or tundra plants of all sizes. For example, global survey reports of Heskel et al. (2016) the average a coefficient to be -2.05 across all NLEv trees, -2.00 in the boreal biome and -1.6 in the Tundra biome, while we report -1.2 for trees and -0.7 saplings at the FTE. In contrast to these differences in $a$, there were no differences in either the slope $(b)$ or curvature $(c)$ of the modeled temperature responses between the two size classes at the FTE, which is in contrast to our hypothesis. The lack of change in these coefficients suggests that as temperatures change (over the course of the day, the season or perhaps even over the years), respiratory rates will not be moderated and will remain high across all temperatures. This pattern is functionally similar to the theoretical "Type II acclimation" [an upwards shift in low temperature respiration,
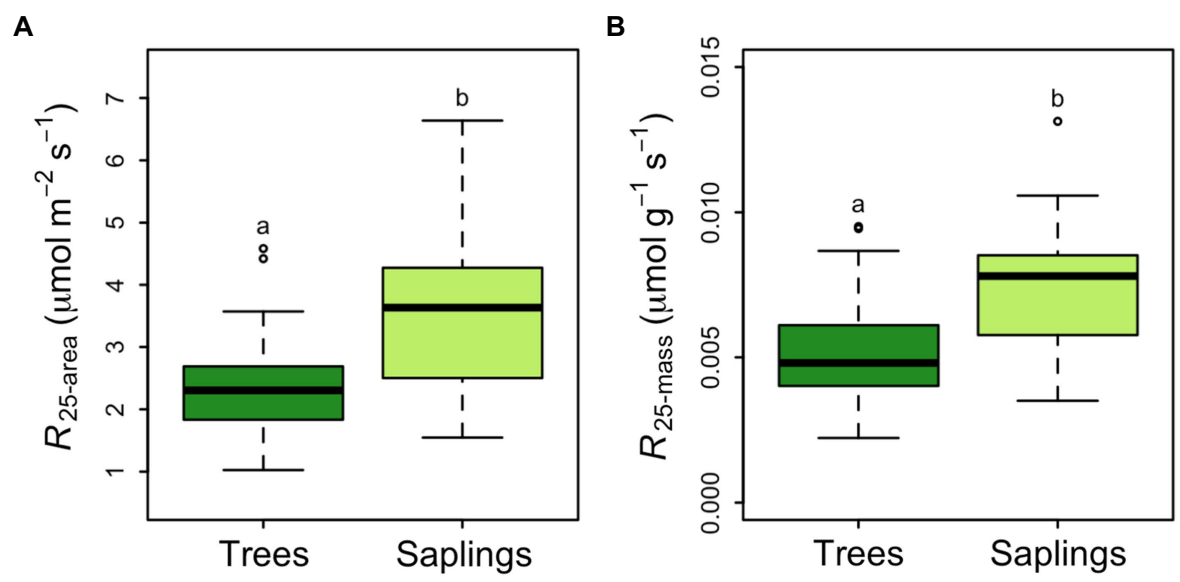

FIGURE 4 | Picea glauca leaf respiration normalized to $25^{\circ} \mathrm{C}$, as a function of tree size at the FTE in Alaska. Respiration is expressed as a function of leaf area (A) and leaf mass (B). Boxplots represent the median and the first and third quartiles. Whiskers delimit the range for each group, with outliers falling outside 1.5 times the interquartile range marked by points. Significant differences between groups are marked by different letters $(p<0.05)$. Dark green boxes $=$ trees $\geq 10 \mathrm{~cm}$ $\mathrm{DBH}$, light green boxes $=$ saplings $5-10 \mathrm{~cm} \mathrm{DBH} . n=36$. 


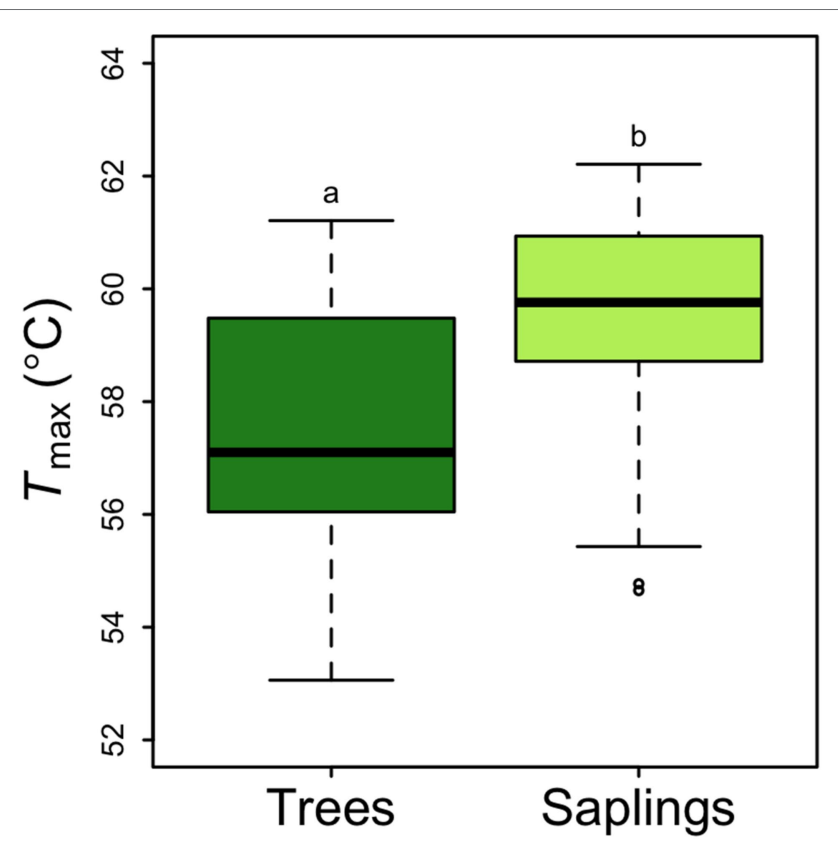

FIGURE 5 | Picea glauca $T_{\max }$ (the leaf temperature corresponding to the maximum rate of respiration), as a function of tree size at the FTE in Alaska. Boxplot represent the median and the first and third quartiles. Whiskers delimit the range for each group, with outliers falling outside 1.5 times the interquartile range marked by points. Significant differences between groups are marked by different letters $(p<0.05)$. Dark green box $=$ trees $\geq 10 \mathrm{~cm} \mathrm{DBH}$, light green box = saplings $5-10 \mathrm{~cm} \mathrm{DBH}$. $n=36$.

or coefficient $a$, without changes in the overall shape ( $b$ and c; Atkin and Tjoelker, 2003)], which has been attributed to limited respiratory enzyme capacity. The shape of the FTE $\mathrm{R} / \mathrm{T}$ response (as defined by the $b$ and $c$ coefficients of the model) also deviates significantly from the average responses of both the Tundra biome and NLEv PFT, but is similar to that of the Boreal biome (collected with similar techniques, Heskel et al., 2016). The high respiratory costs of saplings at the FTE are thus unique (Heskel et al., 2016) and may be rooted in the limited capacity of their respiratory enzymes. Any number of environmental and biological conditions may contribute, but clearly across ecologically relevant temperatures, the FTE saplings have higher respiratory carbon losses that must be overcome to survive.

What drives higher respiratory rates in saplings compared to trees at the FTE, and in white spruce at the FTE compared to other species of similar functional types, or growing in neighboring biomes more generally? We have only limited ability to answer this question, but find no evidence of differences in nitrogen nutrition (large trees had similar leaf nitrogen concentrations to saplings and we found no relationship between leaf $\mathrm{N}$ and $R_{25}$ or $a$ ), water availability (similar \% leaf water content) or structural investment (similar LDMC, SLA, and consistent differences in area and massed based respiration rates). Instead, we suggest that faster relative growth rates of the saplings at this site (Jensen et al., unpublished), and presumably higher maintenance costs, both contribute.
Additional studies designed to separate growth and maintenance respiration (Amthor, 1984) would provide insight, as would detailed quantification of the microenvironment as a function of tree size (Scott et al., 1987; Smith et al., 2009; Moser et al., 2010; Körner, 2012b; Maguire et al., 2019), with particular focus on the interactions among temperature, wind speed and vapor pressure deficit (e.g., Squeo et al., 1991; Holmgren et al., 1996; Holtmeier, 2009; Maguire et al., 2019).

An additional piece of information available in the highresolution temperature response curves is $T_{\max }$, the temperature at which the highest respiration rate was achieved. This temperature is related to leaf death, and at temperatures exceeding $T_{\max }$, respiration drops precipitously and irreversibly (O'Sullivan et al., 2013). Our estimates of $T_{\max }$ are quite high but within the upper bounds of the global survey of O'Sullivan et al. (2017). However, our results stand out from the latitudinal patterns found by O'Sullivan et al. (2017) clearly show a decreasing $T_{\max }$ at higher absolute latitudes and thus would predict much lower $T_{\max }$ values at the FTE. In fact, the $T_{\max }$ we report here for white spruce within the FTE is much closer to the lowest absolute latitude samples and highest maximum temperature sites from the cross-biome survey (O'Sullivan et al., 2017). This earlier work concluded that plants at mid-latitude sites were operating closest to, and sometimes outside of, the respiratory thermal safety margin (e.g., the difference between $T_{\max }$ and the mean maximum daily temperature over the warmest consecutive 3-day period) and were most at risk for mortality during heat waves (O'Sullivan et al., 2017). By contrast, plants growing at either high or low latitudes were found to have the highest margin of safety and were unlikely to be damaged by heat wave events. In comparison, we find that the thermal safety margin at the FTE is curiously high, suggesting that white spruce growing at treeline is at very low risk for thermal damage, even during extreme heat waves with temperatures as unrealistically high as $59^{\circ} \mathrm{C}$. The reason for this high temperature tolerance is unknown, but perhaps related to leaf morphology, tree age (having experienced a greater range of temperatures), or the magnitude of the respiratory "burst" (Hüve et al., 2011, 2012; O'Sullivan et al., 2017). The respiratory burst is thought to emanate from heat-induced changes in membrane properties and the rate of ATP synthesis and/or demand (Berry and Bjorkman, 1980; Seemann et al., 1984; Hazel, 1995; Sung et al., 2003; Zhu et al., 2018). While heat wave events may not challenge white spruce directly, indirectly the effects of rising temperature on leaf and tree carbon balance could still hamper sapling survival and provide the mechanism linking treeline locations to temperature as suggested by Körner (2012b).

Warming in the Arctic is dramatic and occurring much faster than at lower latitudes (Huang et al., 2017). Furthermore, the rate of warming will be exacerbated by continued greenhouse gas emissions. Predictions for the interior of Alaska are for an additional temperature increase of up to $6^{\circ} \mathrm{C}$ by the end of the century (Markon et al., 2012). As thermal acclimation of respiration has been shown to be limited in white spruce (Benomar et al., 2018), respiration rates within the FTE could increase significantly under these scenarios. Currently June, July, and August temperatures average approximately $15^{\circ} \mathrm{C}$ (Harris and Jones, 2017; 
Zepner et al., 2021). If these average temperatures were to increase to $21^{\circ} \mathrm{C}$, we estimate that leaf respiration would increase by $55 \%$, from 1.07 to $1.70 \mu \mathrm{molm}^{-2} \mathrm{~s}^{-1}$ in trees and 1.56 to $2.42 \mu \mathrm{molm}^{-2} \mathrm{~s}^{-1}$ in saplings. Despite the potential for photosynthesis to acclimate to higher temperatures, Stinziano and Way (2017) found that with warming, white spruce allocates additional carbon to respiration rather than to growth. We conclude that this carbon balance challenge may be particularly acute at the FTE. Further studies of the physiological mechanisms involved, such as photosynthesis, respiration and growth, are urgently needed.

\section{CONCLUSION}

In his influential book on treeline, Körner (2012b) describes the sapling stage as being the most critical for woody plant survival at or near treeline.

\begin{abstract}
After seedling establishment, the most critical life stage is the emergence from the aerodynamic boundary provided by alpine heathland or by micro-topography to the open convective conditions in the free atmosphere. This transition is a continuous "fight" that led to the German term "kampfzone," describing the uppermost belt of the ecotone, where trees quite often lose the fight and remain crippled, forming shrub-like structures termed "krummholz." Perhaps, this is the central question of treeline formation, what causes tree species to remain confined to the shrub layer rather than to grow into upright trees. (Page 122)
\end{abstract}

Here, we show that saplings struggling to grow beyond the aerodynamic boundary layer have higher rates of respiration and thus incur a carbon cost beyond what is present in established trees. The higher respiration rate is not accompanied by a change in the shape of the temperature response curve and thus the additional cost, above that of the trees, will be incurred at all temperatures. These findings partially support our second hypothesis. However, we found no support for our first hypothesis on the effect of canopy position. Respiratory characteristics of leaves at the top of the canopy were no different from those of leaves at the bottom of the canopy. We have demonstrated that compared to previous measurements from the Tundra or Boreal biomes, as well as the global average of the NLEv plant functional type, the needles of white spruce growing at the Alaskan FTE are respiring at what are likely the species extremes as demonstrated by their very high respiratory rates at a common temperature, their high measured $T_{\max }$, and the lack of acclimation in the shape of temperature response of respiration. Our findings suggest the capacity of respiratory enzymes could be limiting the rate

\section{REFERENCES}

ACIA (2005). Arctic Climate Impact Assessment. Cambridge: Cambridge University Press. Amthor, J. S. (1984). The role of maintenance respiration in plant growth. Plant Cell Environ. 7, 561-569. doi: 10.1111/j.1365-3040.1984.tb01856.x

Atkin, O. K., Bloomfield, K. J., Reich, P. B., Tjoelker, M. G., Asner, G. P., Bonal, D., et al. (2015). Global variability in leaf respiration in relation to of respiration of this species at treeline. Without thermal acclimation, respiratory carbon release could be as much as $57 \%$ higher by the end of the century and potentially preclude the predicted (but not often observed) advance of the FTE. A more robust examination of the physiological processes contributing to leaf and tree carbon balance at the FTE is urgently needed.

\section{DATA AVAILABILITY STATEMENT}

The datasets presented in this study can be found in online repositories. The names of the repository/repositories and accession number(s) can be found at: Griffin et al. (2021).

\section{AUTHOR'S NOTE}

This paper is dedicated to the memory of James N. Siedow, Professor of Botany at Duke University. I am honored to have learned from, and to have been inspired by Jim. I will always be grateful for the time he spent helping me, the depth of education he gave me, and his steady mentoring as part of my thesis committee. His devotion to science and push for deeper knowledge of plant respiration set an example for all of us, particularly those who were lucky enough to study with him. Jim was also a memorable Father Christmas at the departmental holiday parties, always keeping us laughing with his particular brand of quick wit and sarcasm. - Kevin L. Griffin.

\section{AUTHOR CONTRIBUTIONS}

KG, SS, NB, LV, and JE designed the research and participated in data collection with the assistance of SB. SS and KG analyzed the data. KG wrote the first draft of the manuscript. All authors contributed to the article and approved the submitted version.

\section{FUNDING}

This work was supported by NASA ABoVE grant NNX15AT86A and the Arctic LTER (NSF Grant No. 1637459).

\section{ACKNOWLEDGMENTS}

We thank Sarah Sackett from the NASA ABoVE support team in Fairbanks, AK, for logistical support during Alaska field campaigns. We also thank Zoe M. Griffin for lab assistance. doi: $10.1111 / \mathrm{nph} .13253$

Atkin, O., and Tjoelker, M. G. (2003). Thermal acclimation and the dynamic response of plant respiration to temperature. Trends Plant Sci. 8, 343-351. doi: 10.1016/S1360-1385(03)00136-5

Awada, T., and Redmann, R. E. (2000). Acclimation to light in planted and naturally regenerated populations of white spruce seedlings. Can. J. Bot. 78, 1495-1504. doi: 10.1139/cjb-78-12-1495 
Bates, D., Maechler, M., Bolker, B., and Walker, S. (2015). Fitting linear mixedeffects models using lme4. J. Stat. Softw. 67, 1-48. doi: 10.18637/jss.v067.i01

Benomar, L., Lamhamedi, M. S., Pepin, S., Rainville, A., Lambert, M. C., Margolis, H. A., et al. (2018). Thermal acclimation of photosynthesis and respiration of southern and northern white spruce seed sources tested along a regional climatic gradient indicates limited potential to cope with temperature warming. Ann. Bot. 121, 443-457. doi: 10.1093/aob/mcx174

Berry, J., and Bjorkman, O. (1980). Photosynthetic response and adaptation to temperature in higher plants. Annu. Rev. Plant Physiol. 31, 491-543. doi: 10.1146/annurev.pp.31.060180.002423

Brienen, R. J. W., Caldwell, L., Duchesne, L., Voelker, S., Barichivich, J., Baliva, M., et al. (2020). Forest carbon sink neutralized by pervasive growth-lifespan trade-offs. Nat. Commun. 11:4241. doi: 10.1038/s41467-020-17966-z

Callaghan, T. V., Crawford, R. M. M., Eronen, M., Hofgaard, A., Payette, S., Rees, W. G., et al. (2002a). The dynamics of the tundra-taiga boundary: an overview and suggested coordinated and integrated approach to research. Ambio 31, 3-5. doi: 10.2307/25094569

Callaghan, T. V., Werkman, B. R., and Crawford, R. M. M. (2002b). The tundrataiga interface and its dynamics: concepts and applications. Ambio 12, 6-14.

Cohen, J., Screen, J. A., Furtado, J. C., Barlow, M., Whittleston, D., Coumou, D., et al. (2014). Recent Arctic amplification and extreme mid-latitude weather. Nat. Geosci. 7, 627-637. doi: 10.1038/ngeo2234

Colesie, C., Stangl, Z. R., and Hurry, V. (2020). Differences in growth-economics of fast vs. slow growing grass species in response to temperature and nitrogen limitation individually, and in combination. BMC Ecol. 20:63. doi: 10.1186/ s12898-020-00333-3

Eitel, J. U. H., Griffin, K. L., Boelman, N. T., Maguire, A. J., Meddens, A. J. H., Jensen, J., et al. (2020). Remote sensing tracks daily radial wood growth of evergreen needleleaf trees. Glob. Chang. Biol. 26, 4068-4078. doi: 10.1111/ gcb. 15112

Eitel, J. U. H., Maguire, A. J., Boelman, N., Vierling, L. A., Griffin, K. L., Jensen, J., et al. (2019). Proximal remote sensing of tree physiology at northern treeline: do late-season changes in the photochemical reflectance index (PRI) respond to climate or photoperiod? Remote Sens. Environ. 221, 340-350. doi: 10.1016/j.rse.2018.11.022

Fisher, J. B., Hayes, D. J., Schwalm, C. R., Huntzinger, D. N., Stofferahn, E., Schaefer, K., et al. (2018). Missing pieces to modeling the Arctic-boreal puzzle. Environ. Res. Lett. 13:8. doi: 10.1088/1748-9326/aa9d9a

Fisher, J. B., Sikka, M., Oechel, W. C., Huntzinger, D. N., Melton, J. R., Koven, C. D., et al. (2014). Carbon cycle uncertainty in the Alaskan Arctic. Biogeosciences 11, 4271-4288. doi: 10.5194/bg-11-4271-2014

Griffin, K. L., Schmiege, S. C., Bruner, S. G., Boelman, N., Vierling, L., and Eitel, J. (2021). Spruce Leaf and Tree Traits, Water Vapor and CO2 Exchange, Arctic Treeline, AK, 2018. Oak Ridge, Tennessee, USA: ORNL DAAC.

Griffin, K. L., Tissue, D. T., Turnbull, M. H., Schuster, W., and Whitehead, D. (2001). Leaf dark respiration as a function of canopy position in Nothofagus fusca trees grown at ambient and elevated $\mathrm{CO}_{2}$ partial pressures for 5 years. Funct. Ecol. 15, 497-505. doi: 10.1046/j.0269-8463.2001.00539.x

Griffin, K. L., Turnbull, M., and Murthy, R. (2002). Canopy position affects the temperature response of leaf respiration in Populus deltoides. New Phytol. 154, 609-619. doi: 10.1046/j.1469-8137.2002.00410.x

Harris, I. C., and Jones, P. D. (2017). CRU TS4. 01: Climatic Research Unit (CRU) Time-Series (TS) version 4.01 of high-resolution gridded data of month-by-month variation in climate (Jan. 1901-Dec. 2016). Centre for Environmental Data Analysis, 25.

Hazel, J. R. (1995). Thermal adaptation in biological membranes: is homeoviscous adaptation the explanation? Annu. Rev. Physiol. 57, 19-42. doi: 10.1146/ annurev.ph.57.030195.000315

Heskel, M. A., Greaves, H. E., Turnbull, M. H., O'Sullivan, O. S., Shaver, G. R., Griffin, K. L., et al. (2014). Thermal acclimation of shoot respiration in an Arctic woody plant species subjected to 22 years of warming and altered nutrient supply. Glob. Chang. Biol. 20, 2618-2630. doi: 10.1111/gcb.12544

Heskel, M. A., O'Sullivan, O. S., Reich, P. B., Tjoelker, M. G., Weerasinghe, L. K., Penillard, A., et al. (2016). Convergence in the temperature response of leaf respiration across biomes and plant functional types. Proc. Natl. Acad. Sci. U. S. A. 113, 3832-3837. doi: 10.1073/pnas.1520282113

Holmgren, B., Ovhed, M., and Karlsson, P. S. (1996). Measuring and modeling stomatal and aerodynamic conductances of mountain birch: implications for treeline dynamics. Arct. Alp. Res. 28, 425-434. doi: 10.2307/1551853
Holtmeier, F.-K. (2009). Mountain Timberlines: Ecology, Patchiness, and Dynamics. 2nd Edn. Netherlands: Springer.

Huang, J. B., Zhang, X. D., Zhang, Q. Y., Lin, Y. L., Hao, M. J., Luo, Y., et al. (2017). Recently amplified arctic warming has contributed to a continual global warming trend. Nat. Clim. Chang. 7, 875-879. doi: 10.1038/ s41558-017-0009-5

Huntingford, C., Atkin, O. K., Martinez-De La Torre, A., Mercado, L. M., Heskel, M. A., Harper, A. B., et al. (2017). Implications of improved representations of plant respiration in a changing climate. Nat. Commun. 8:1602. doi: 10.1038/s41467-017-01774-z

Hüve, K., Bichele, I., Ivanova, H., Keerberg, O., Parnik, T., Rasulov, B., et al. (2012). Temperature responses of dark respiration in relation to leaf sugar concentration. Physiol. Plant. 144, 320-334. doi: 10.1111/ j.1399-3054.2011.01562.x

Hüve, K., Bichele, I., Rasulov, B., and Niinemets, U. (2011). When it is too hot for photosynthesis: heat-induced instability of photosynthesis in relation to respiratory burst, cell permeability changes and $\mathrm{H}_{2} \mathrm{O}_{2}$ formation. Plant Cell Environ. 34, 113-126. doi: 10.1111/j.1365-3040.2010.02229.x

Körner, C. (1998). A re-assessment of high elevation treeline positions and their explanation. Oecologia 115, 445-459. doi: 10.1007/s004420050540

Körner, C. (2012a). Treelines will be understood once the functional difference between a tree and a shrub is. Ambio 41, 197-206. doi: 10.1007/ s13280-012-0313-2

Körner, C. (2012b). Alpine Treelines. Basel: Springer.

Körner, C., and Paulsen, J. (2004). A world-wide study of high altitude treeline temperatures. J. Biogeogr. 31, 713-732. doi: 10.1111/j.1365-2699.2003.01043.x

Kuznetsova, A., Brockhoff, P., and Christensen, R. (2017). lmerTest package: tests in linear mixed effects models. J. Stat. Softw. 82, 1-26. doi: 10.18637/ jss.v082.i13

Li, W., Ciais, P., Wang, Y. L., Yin, Y., Peng, S. S., Zhu, Z. C., et al. (2018). Recent changes in global photosynthesis and terrestrial ecosystem respiration constrained from multiple observations. Geophys. Res. Lett. 45, 1058-1068. doi: 10.1002/2017GL076622

Li, X. M., Xu, C. Y., Li, Z. Z., Feng, J. C., Tissue, D. T., and Griffin, K. L. (2019). Late growing season carbon subsidy in native gymnosperms in a northern temperate forest. Tree Physiol. 39, 971-982. doi: 10.1093/treephys/ tpz024

Maguire, A. J., Eitel, J. U. H., Griffin, K. L., Magney, T. S., Long, R. A. Vierling, L. A., et al. (2020). On the functional relationship between fluorescence and photochemical yields in complex evergreen needleleaf canopies. Geophys. Res. Lett. 47:9. doi: 10.1029/2020GL087858

Maguire, A. J., Eitel, J. U. H., Vierling, L. A., Johnson, D. M., Griffin, K. L., Boelman, N. T., et al. (2019). Terrestrial lidar scanning reveals fine-scale linkages between microstructure and photosynthetic functioning of smallstature spruce trees at the forest-tundra ecotone. Agric. For. Meteorol. 269-270, 157-168. doi: 10.1016/j.agrformet.2019.02.019

Man, R. Z., and Lieffers, V. J. (1997). Seasonal photosynthetic responses to light and temperature in white spruce (Picea glauca) seedlings planted under an aspen (Populus tremuloides) canopy and in the open. Tree Physiol. 17, 437-444. doi: 10.1093/treephys/17.7.437

Markon, C. J., Trainor, S. F., and Chapin, F. S. III. (2012). The United States National Climate Assessment - Alaska Technical Regional Report.

McNown, R. W., and Sullivan, P. F. (2013). Low photosynthesis of treeline white spruce is associated with limited soil nitrogen availability in the western Brooks Range, Alaska. Funct. Ecol. 27, 672-683. doi: 10.1111/1365-2435.12082

Moser, L., Fonti, P., Buntgen, U., Esper, J., Luterbacher, J., Franzen, J., et al. (2010). Timing and duration of European larch growing season along altitudinal gradients in the Swiss Alps. Tree Physiol. 30, 225-233. doi: 10.1093/ treephys/tpp108

Nienstaedt, H., and Zasada, J. C. (1990). "Picea glauca (Moench) Voss white spruce," in Silvics of North America: Vol. 1: Conifer. eds. R. M. Burns and B. H. Honkala (Washington, DC: US Department of Agriculture, Forest Service), 204-226.

O'Sullivan, O. S., Heskel, M. A., Reich, P. B., Tjoelker, M. G., Weerasinghe, L. K., Penillard, A., et al. (2017). Thermal limits of leaf metabolism across biomes. Glob. Chang. Biol. 23, 209-223. doi: 10.1111/gcb.13477

O'Sullivan, O. S., Weerasinghe, K., Evans, J. R., Egerton, J. J. G., Tjoelker, M. G., and Atkin, O. K. (2013). High-resolution temperature responses of leaf respiration in snow gum (Eucalyptus pauciflora) reveal high-temperature 
limits to respiratory function. Plant Cell Environ. 36, 1268-1284. doi: 10.1111/ pce. 12057

Pampuch, T., Anadon-Rosell, A., Zacharias, M., von Arx, G., and Wilmking, M. (2020). Xylem anatomical variability in white spruce at treeline is largely driven by spatial clustering. Front. Plant Sci. 11:581378. doi: 10.3389/fpls.2020.581378

Patterson, A. E., Arkebauer, R., Quallo, C., Heskel, M. A., Li, X. M., Boelman, N., et al. (2018). Temperature response of respiration and respiratory quotients of 16 co-occurring temperate tree species. Tree Physiol. 38, 1319-1332. doi: 10.1093/treephys/tpx176

Pearson, R. G., Phillips, S. J., Loranty, M. M., Beck, P. S. A., Damoulas, T., Knight, S. J., et al. (2013). Shifts in Arctic vegetation and associated feedbacks under climate change. Nat. Clim. Chang. 3, 673-677. doi: 10.1038/nclimate1858

Poorter, H., Lambers, H., and Evans, J. R. (2014). Trait correlation networks: a whole-plant perspective on the recently criticized leaf economic spectrum. New Phytol. 201, 378-382. doi: 10.1111/nph.12547

Poorter, H., and Pothmann, P. (1992). Growth and carbon economy of a fastgrowing and a slow-growing grass species as dependent on ontogeny. New Phytol. 120, 159-166. doi: 10.1111/j.1469-8137.1992.tb01069.x

Prud'Homme, G. O., Lamhamedi, M. S., Benomar, L., Rainville, A., DeBlois, J., Bousquet, J., et al. (2018). Ecophysiology and growth of white spruce seedlings from various seed sources along a climatic gradient support the need for assisted migration. Front. Plant Sci. 8:2214. doi: 10.3389/fpls.2017.02214

R Core Team (2020). R: A Language and Environment for Statistical Computing. $\mathrm{R}$ Foundation for Statistical Computing.

Reich, P. B., Rich, R. L., Lu, X., Wang, Y. P., and Oleksyn, J. (2014). Biogeographic variation in evergreen conifer needle longevity and impacts on boreal forest carbon cycle projections. Proc. Natl. Acad. Sci. 111, 13703-13708. doi: 10.1073/ pnas. 1216054110

Schmiege, S. C., Buckley, B. M., Stevenson, D. W., Heskel, M. A., Cuong, T. Q., Nam, L., et al. (2021). Respiratory temperature responses of tropical conifers differ with leaf morphology. Funct. Ecol. 35, 1408-1423. doi: 10.1111/1365-2435.13814

Schneider, C. A., Rasband, W. S., and Eliceiri, K. W. (2012). NIH image to Image): 25 years of image analysis. Nat. Methods 9, 671-675. doi: 10.1038/nmeth.2089

Schuur, E. A. G., McGuire, A. D., Schadel, C., Grosse, G., Harden, J. W., Hayes, D. J., et al. (2015). Climate change and the permafrost carbon feedback. Nature 520, 171-179. doi: 10.1038/nature14338

Scott, P. A., Bentley, C. V., Fayle, D. C. F., and Hansell, R. I. C. (1987). Crown forms and shoot elongation of white spruce at the treeline, Churchill, Manitoba, Canada. Arct. Alp. Res. 19, 175-186. doi: 10.2307/1551250

Seemann, J. R., Berry, J. A., and Downton, W. J. S. (1984). Photosynthetic response and adaptation to high-temperature in desert plants - a comparison of gas-exchange and fluorescence methods for studies of thermal tolerance. Plant Physiol. 75, 364-368. doi: 10.1104/pp.75.2.364

Smith, W. K., Germino, M. J., Johnson, D. M., and Reinhardt, K. (2009). The altitude of alpine treeline: a bellwether of climate change effects. Bot. Rev. 75, 163-190. doi: 10.1007/s12229-009-9030-3

Squeo, F. A., Rada, F., Azocar, A., and Goldstein, G. (1991). Freezing tolerance and avoidance in high tropical Andean plants - is it equally represented in species with different plant height? Oecologia 86, 378-382. doi: 10.1007/BF00317604

Stinziano, J. R., and Way, D. A. (2017). Autumn photosynthetic decline and growth cessation in seedlings of white spruce are decoupled under warming and photoperiod manipulations. Plant Cell Environ. 40, 1296-1316. doi: $10.1111 /$ pce. 12917

Sung, D. Y., Kaplan, F., Lee, K. J., and Guy, C. L. (2003). Acquired tolerance to temperature extremes. Trends Plant Sci. 8, 179-187. doi: 10.1016/ S1360-1385(03)00047-5

Sutton, R. F. (1969). The Silvics of White Spruce (Picea glauca (Moench) Voss. Vol. 1250. Canada: Forest Research Division, Forestry Branch.

Sveinbjornsson, J., Hofgaard, A., and Lloyd, A. (2002). Natural causes of the tundra-taiga boundary. Ambio 31, 23-29.

Valentini, R., Matteucci, G., Dolman, A. J., Schulze, E. D., Rebmann, C., Moors, E. J., et al. (2000). Respiration as the main determinant of carbon balance in European forests. Nature 404, 861-865. doi: 10.1038/ 35009084

Weger, H. G., and Guy, R. D. (1991). Cytochrome and alternative pathway respiration in white spruce (Picea glauca) roots - effects of growth and measurement temperature. Physiol. Plant. 83, 675-681. doi: 10.1111/j.1399-3054.1991.tb02486.x

Whitehead, D., Griffin, K. L., Turnbull, M. H., Tissue, D. T., Engel, V. C., Brown, K. J., et al. (2004). Response of total night-time respiration to differences in total daily photosynthesis for leaves in a Quercus rubra $\mathrm{L}$. canopy: implications for modelling canopy $\mathrm{CO}_{2}$ exchange. Glob. Chang. Biol. 10, 925-938. doi: 10.1111/j.1529-8817.2003.00739.x

Zepner, L., Karrasch, P., Wiemann, F., and Bernard, L. (2021). ClimateCharts. net - an interactive climate analysis web platform. Int. J. Digit. Earth 14, 338-356. doi: 10.1080/17538947.2020.1829112

Zhang, W. X., Miller, P. A., Smith, B., Wania, R., Koenigk, T., and Doscher, R. (2013). Tundra shrubification and tree-line advance amplify arctic climate warming: results from an individual-based dynamic vegetation model. Environ. Res. Lett. 8:10. doi: 10.1088/1748-9326/8/3/034023

Zhu, L. L., Bloomfield, K. J., Hocart, C. H., Egerton, J. J. G., O'Sullivan, O. S., Penillard, A., et al. (2018). Plasticity of photosynthetic heat tolerance in plants adapted to thermally contrasting biomes. Plant Cell Environ. 41, 1251-1262. doi: 10.1111/pce.13133

Conflict of Interest: The authors declare that the research was conducted in the absence of any commercial or financial relationships that could be construed as a potential conflict of interest.

Publisher's Note: All claims expressed in this article are solely those of the authors and do not necessarily represent those of their affiliated organizations, or those of the publisher, the editors and the reviewers. Any product that may be evaluated in this article, or claim that may be made by its manufacturer, is not guaranteed or endorsed by the publisher.

Copyright (C) 2021 Griffin, Schmiege, Bruner, Boelman, Vierling and Eitel. This is an open-access article distributed under the terms of the Creative Commons Attribution License (CC BY). The use, distribution or reproduction in other forums is permitted, provided the original author(s) and the copyright owner(s) are credited and that the original publication in this journal is cited, in accordance with accepted academic practice. No use, distribution or reproduction is permitted which does not comply with these terms. 